\title{
Social Innovation in Tourism Industry: A Case Study on Master's Students ${ }^{1}$
}

\author{
Turizm Sektöründe Sosyal İnovasyon: Yüksek Lisans Öğrencileri Üzerine Bir Araştırma
}

\author{
Nilüfer ZENGİN ${ }^{a}$, Nuray TÜRKER ${ }^{b}$ (i) \\ a Karabuk University, Graduate Education Institute, Tourism Management, Karabuk, Turkey. \\ b Prof., Karabuk University, Safranbolu Faculty of Tourism, Recreation Management, Karabuk, Turkey.
}

\begin{abstract}
For the survival and the competition of tourism enterprises, gaining a good position in the market depends on developing new ideas that can bring solutions to social problems and creating a social impact with innovative approaches. Social innovation pertains to the process of solving social, economic, cultural, political, and ecological problems with innovative policies, processes, and practices. It helps to create social change in tourism, which is a social phenomenon. Considering the importance of developing innovative ideas in the tourism industry, the aim of this research is to collect the socially innovative ideas of Master's class students studying at a state university in Turkey. The current study adopted a qualitative approach through focus group interviews. The sample was chosen among Master class students of Tourism Management and Entrepreneurship. The results suggest that innovative ideas focusing on developing new products/services (new tourism types and destinations), local development, environmental protection, and enhancing tourist experience and customer satisfaction by using information technologies are prominent.
\end{abstract}

Keywords: Social innovation, social entrepreneurship, tourism industry, focus group, students.

\section{Özet}

Turizm işletmelerinin varlıklarını sürdürebilmeleri, rekabet edebilmeleri ve pazarda iyi bir konum elde edebilmeleri toplumsal sorunlara çözüm getirebilecek yeni fikirler geliştirmelerine, yenilikçi yaklaşımlarla sosyal bir etki yaratmalarına bağlıdır. Sosyal inovasyon; sosyal, ekonomik, kültürel, siyasi ve ekolojik sorunların yenilikçi politika, süreç ve uygulamalar ile çözüme kavuşturulması süreci olarak tanımlanmaktadır. Sosyal inovasyon sosyal bir olgu olan turizm alanında sosyal bir değişim yaratmayı amaçlamaktadır. Turizm endüstrisinde yenilikçi fikirlerin geliştirilmesinin öneminden hareketle bu çalışmada; Türkiye'deki bir devlet üniversitesinde öğrenim gören Yüksek Lisans öğrencilerinden turizm sektörü için sosyal yenilikçi fikirler toplanmıştır. Kalitatif araştırma deseninin benimsendiği bu çalışmada; odak grup görüşmeleri yöntemi kullanılmıştır. Örneklem grubunu Turizm İşletmeciliği ve Girişimcilik Yüksek Lisans öğrencileri oluşturmaktadır. Sonuçlar, yaratıcı fikirlerin yeni ürün/hizmet geliştirme (yeni turizm türleri ve destinasyonlar), yerel kalkınma, çevre koruma, bilişim teknolojileri kullanılarak turistik tecrübenin ve müşteri memnuniyetinin arttırılması üzerine odaklandığını göstermektedir.

Anahtar Kelimeler: Sosyal inovasyon, sosyal girişimcilik, turizm endüstrisi, odak grup, öğrenciler.
Article History

Submitted 17.05.2021

Accepted 29.06.2021

Associate Editor

Ali Selçuk CAN

Corresponding Author Nuray Türker nturker@karabuk.edu.tr@

\section{Citation:}

Zengin, N. \& Türker, N. (2021). Social Innovation in Tourism Industry: A Case Study on Master's Students, Journal of Academic Tourism Studies, 2(1): 12-31 


\section{INTRODUCTION}

To adapt to today's rapidly changing competitive environment and meet changing consumer expectations, businesses need to constantly renew and change their services, products, and production methods (Snyder, Witell, Gustafsson, Fombelle, and Kristensson, 2016; Thakur and Hale, 2013). This change and novelty are referred to as "innovation." Social innovation is defined as the process of solving the social, economic, cultural, political, and ecological problems faced by the society with innovative institutions, policies, processes, and practices (Dobele, 2015; Vasin, Gamidullaeva, and Rostovskaya, 2017).

Innovation is the process of transforming new ideas into commercial benefits in every field (Sartori, Costantini, Ceschi, and Tommasi, 2018). The survival of tourism enterprises and their competitiveness depends on the development of novel ideas (Divisekera and Nguyen, 2018). Innovation in the tourism industry does not just refer to the new ideas related to technology. It is also a social process that includes the tourism enterprise's efforts to find innovative solutions to social, ecological, and economic problems. Social innovation aims to create a social change in the field of tourism or by tourism.

The tourism industry has great importance in the world economy as it generates income $(\mathrm{Li}$, Jin, and Shi, 2018). It is an important tool in the development of underdeveloped regions, in reducing unemployment, preventing internal migration, reducing poverty, increasing the quality of life of local people, and eliminating income inequality between regions.

Despite all these benefits of tourism to the world economy, increasing mass tourism, the tourist influx, consumption-oriented movements of people, development of tourism mainly on the coastal areas, which are highly sensitive and fragile, destroying natural resources, and the deterioration of cultural resources have a negative effect on the sustainable development of tourism (Drius, Bongiorni, Depellegrin, Menegon, and Pugnetti, 2019). Due to the seasonal nature of tourism, the concentration of tourism movements at certain places and times increases the pressure on the natural environment (Martin, Martin, Mejia, and Fernandez, 2018). This also leads to many negative economic, socio-cultural, and environmental impacts on the local community living in and around tourism destinations. Solving these problems with socially innovative approaches is vital for both the sustainable development of tourism and the economic welfare of the local people, reducing poverty and increasing quality of life.

Until the 1980s, mass tourism was the dominant type of tourism in the market. The rapid deterioration of the natural environment, the emergence of environmentally sensitive tourists, the change in travel motivations of tourists, in parallel with the efforts of countries to expand tourism to the whole year and the whole country and to benefit from the tourism economy to the maximum extent led tourism types to diversify in the 1990s. For example, new types of tourism have emerged, such as ecotourism, which emphasizes environmental protection and providing economic benefits to the local people (Salman, Jaafar, and Mohamad, 2020). The tourism market is divided into niches (culinary tourism, rural tourism, cultural heritage tourism, health tourism, etc.), considering the travel motivations of tourists.

The emergence of environmentally sensitive tourists has also led to an increase in the environmental protection efforts of tourism enterprises (Neto, 2003). Considering the demands of today's tourists and the damage caused by the tourism industry on the natural environment, many accommodations, food and beverage enterprises, and cruise ships attempt to decrease the negative impacts of tourism by implementing environmental management programs. This has led to the emergence of environmentally sensitive tourism enterprises (Sasidharan, Sirakaya, and Kerstetter, 2002) and subsequently the spread of innovative applications such as green hotels, ecolodges (ecological hotels), eco-friendly hotels, and environmentally friendly accommodations in the tourism industry (Istanbullu Dincer, Akova, Mugan Ertugral, and Aydogan Ciftci, 2017). 
Likewise, rapidly developing information and internet technologies have brought along innovative applications in the tourism industry, and internet technologies have been widely used from air transport and hotel reservations to sales, marketing, and promotional activities of businesses. Tourism businesses that use these information technologies have achieved convenience in sales and reservations and gained a competitive advantage (Zengin and Dursun, 2017). In addition, developing technologies trigger the increase of social innovation and entrepreneurship practices in the tourism industry. Innovations such as information systems, the internet, and virtual reality applications have created radical changes in the industry.

Although the tourism industry is highly developed in the Mediterranean and Aegean coasts in Turkey, all regions are rich in terms of natural and historical resources. High tourism potential has been used for the economic development of the regions and various projects have been developed to make tourism a driving force in rural and regional development. All these projects and practices, which can be considered as social innovation examples, have been important tools in the development of the tourism industry, increasing the competitiveness and the number of tourists, and ensuring local development. For the sustainable development of tourism, such social innovative approaches should continue.

Considering the relevant literature (Zengin and Dursun, 2017; Vatan, 2010; Vatan and Zengin, 2014; Türker and Alaeddinoğlu, 2018; Sofracı and Sarıkaya, 2017; Kazançoğlu and Dirsehan, 2016; Iş1k, 2018), the fact that there are a limited number of studies on social innovation and social entrepreneurship in the tourism industry increases the importance of this study. Hence, this study aimed at developing socially innovative ideas that can be applied in the tourism industry. The results of this study will provide important implications for institutions such as tourism enterprises, local governments, non-governmental organizations, etc., in terms of solving the problems of society, elimination of development problems in underdeveloped regions through tourism, and increasing awareness towards environmental problems.

\section{LITERATURE}

\subsection{Social Innovation and Social Entrepreneurship}

Social innovation refers to the search for innovative ways to address the problems and needs of society. It includes the development and implementation of innovation, change, and improvement to activities that will benefit all parties of a society. Social innovation offers new solutions to social problems related to the economy, health, and education (Datta, 2011). Social innovation is novel or improved practices, initiatives, and services that are carried out to find solutions to social problems (cultural, social, and economic) (Goldenberg, 2004; Tanimoto and Doi, 2007). A true social innovation permanently changes perceptions, behaviors, structures, and systems (Chiklyaukova, 2015).

Haugh (2005: 5, cited in Kahvecioğlu, 2017), defined social innovation as the provision of new services in areas where social problems such as accommodation, education, health, culture, employment, and environment can be observed, implementation of new income-generating activities, and the adoption of strategies to find new resources by expanding the people who benefit from the services. According to Ruiz and Parra (2013), social innovation is the process of policies, designs, and practices that initiate innovative change to achieve economic output in social organizations.

Considering the definitions, it is seen that social innovation focuses on solving various social problems such as economic, social, environmental, and educational and improving people's life. Social innovation is novel ideas, practices, initiatives, structures (organizations), business models, and/or processes developed to find more effective solutions to these problems. Social innovation stems from social needs. 
The roots of the social innovation approach date to the 1700s. Innovation theory has a history extending to the studies of Max Weber and Emile Durkheim who were interested in social change, and Parsons's analysis of social movements (Topsakal and Yüzbaşığlu, 2017, Milliyet newspaper, 2013). Social innovation was first discussed in the late 19th century by Max Weber under the name of "social inventions."

The necessity of social innovation and its relationship with technology and innovation to ensure economic efficiency was first revealed by Joseph Schumpeter in the 1930s (Seçkin Halaç, Eren, and Bulut, 2014). Joseph Schumpeter, an economist, and political scientist stated that innovation should include social areas beyond its technological meaning (Schumpeter, 1934). With his "destructive creativity" theory, Schumpeter stated that innovation is an important element of social change. Social innovation also stands out in the works of Peter Drucker and Michael Young in the 1960s (Milliyet newspaper, 2013).

In the 2000s, social innovation has become an important phenomenon. Bangladeshi economics professor and banker Muhammed Yunus and Grameen Bank's micro-credit project had a great impact on the development and popularization of social innovation. With this project, which was developed in 2006, Yunus enabled poor women to establish small businesses by allocating microloans that banks avoid, thus creating a social innovation.

According to Moulaert et al. (2005, cited by Topsakal and Yüzbaşığlu, 2017), social innovation has three main dimensions. The first one is the product dimension that focuses on meeting the previously unfulfilled needs of people. The second dimension is the process dimension that provides a change in social relations by increasing participation in all segments of the society. The third dimension is the strengthening dimension.

According to the Bureau of European Policy Advisers (BEPA), social innovation consists of two basic approaches. The first one is innovative solutions to social demands. In other words, it is the introduction of innovative practices instead of traditional methods to meet the social needs of vulnerable groups in the society. Thus, innovative solutions are offered to new social problems in the society. The second approach is social design. Social design stems from the need for change. With this approach, solutions to social and economic problems are produced by empowering people at the local level (European Commission, 2013; Özmete and Gök, 2015).

There are many social innovation examples. To illustrate, the "modern aging program" launched in Sweden aims to develop creative ideas that enhance the daily lives of older people. Using mobile phone software, the closest volunteer can purchase goods for an old person. Another example is Magic Bus, which provides education and guidance to young people and children in regions in India where educational opportunities are not available and infrastructure is not sufficient. In South Korea, the Hope Institute, which conducts socially innovative studies, has developed a mobile phone game that encourages tree planting (Ateş, 2018).

Social innovation efforts have been increasing in Turkey. Examples of social innovations in Turkey include Umut Houses, which allow disabled people to live together in small groups in an apartment or a detached house with other neighbors; Mor Çatı Women's Shelter Foundation, which was founded to shelter women subjected to physical, economic, verbal, psychological or sexual violence and to provide psychological and legal support, to support health, education and employment needs; a coffee shop "demgoodcoffee" run by the hearing impaired people are the (Kahvecioğlu, 2017).

Social entrepreneurship is an innovative activity that emerges for social purposes. Social entrepreneurship includes the initiatives that create social value (Ercan, 2016). According to Perrini and Vurro (2006), social entrepreneurship is a dynamic process created by people or communities aiming to achieve success in the market or society with a novel idea by using social innovation to create a new social benefit. 
Social entrepreneurship consists of activities that create social value, it focuses on reducing social problems and achieving social change. Social entrepreneurship includes sustainable social projects of commercial enterprises or non-profit organizations and public institutions that bring innovation and create a difference in the society.

The main purpose of social entrepreneurship is to create innovative social enterprises with entrepreneurial approaches by focusing on social issues and creating a social impact. Social entrepreneurship contributes to society socially, environmentally, and economically (Ercan, 2016). Social entrepreneurship can bring about social change in society by educating people, improving their quality of life with new employment opportunities, and contributing to the sustainability of the natural environment.

Although the concept of social entrepreneurship is seen as a new concept, there are examples of social entrepreneurship throughout the history of humanity (Taş and Şemşek, 2017). For example, the first nursing school founded by Florence Nightingale in order to improve hospital conditions and Darüşşafaka, which was founded by Yusuf Ziya in 1872 to provide educational scholarships to students whose parents have passed away, are early examples of social entrepreneurship (Asılsoy, 2016).

Social entrepreneurship has developed with the increase of social problems that arose with the industrial revolution. H. Bowen first used the concept of social entrepreneurship in his book "Social Responsibilities of the Businessman" published in 1953 (Budak, 2015).

Social innovation and social entrepreneurship are interrelated concepts (Özdemir and Ar, 2015). Social entrepreneurs create social innovation. Social entrepreneurs are those who create innovative programs, processes, and products for solving social problems or initiating social innovations (Eren, 2010).

\subsection{Social Innovation and Social Entrepreneurship in the Tourism Industry}

The use of tourism-oriented innovative ideas and initiatives in solving social problems has rapidly increased in recent years. Especially the projects initiated with the public and nongovernmental organizations have created remarkable changes in local development and people's quality of life.

Benevides et al. (2018) defines social innovation in tourism as the implementation of regional policies in order to create employment, promote local culture, increase regional income and protect natural resources. Social enterprise in tourism is called "responsible tourism that creates social and financial added value in the supply chain, is financially self-sufficient, contributes to alleviating poverty and protecting the environment" (Günlü, 2015).

Tourism contributes to the economic development of undeveloped or underdeveloped rural areas due to income generation and increasing employment. In this context, tourism ensures a fair distribution of income in society and that all regions benefit from the income-generating effect of the tourism industry. Tourism contributes to the development of democracy, the empowerment of women in underdeveloped regions, and the development of women's rights. (Öztaş and Karabulut, 2006). Tourism creates interaction between local people and tourists, bringing people from different cultures closer to each other and contributing to the development of friendship, tolerance, and world peace.

In addition to all these positive economic contributions; the uncontrolled development of tourism creates destruction on the physical and socio-cultural environment. Sustainable development of tourism has been neglected in the long run, as the tourism stakeholders (tourism enterprises, local communities, national and local government et.) focus on the economic benefits of tourism in the short term. The negative impacts of tourism affect the socio-cultural life and quality of life of local people negatively, especially those living in tourism destinations. In this context, social innovative approaches are needed to avoid these negative impacts. 
The following issues have priorities in terms of social innovation practices in the tourism industry (Betil, 2010; Eren, 2010; Mulgan, 2006).

- Poverty reduction,

- Creation of new employment areas,

- Urbanization,

- Eliminating injustice related to living standards between regions,

- Migrations,

- Environmental problems such as the decrease in water resources, global warming, carbon emissions, and the energy provided by nonrenewable resources,

- Women's rights,

- Gender equality,

- Consumer rights,

- Expectations of consumers,

- Health and nutrition,

- Protecting nature,

- Improving the ability of the individuals,

- Education rights for all and access to education,

- Supporting disadvantaged groups,

- Ethical problems in working life.

Ergul and Johnson (2011) state that innovation in tourism today is limited to product development, sustainability issues, and ecotourism initiatives, which can be expressed as social entrepreneurship rather than social innovation. Product or service innovation in tourism is carried out in three ways as new product development, supporting products, and product differentiation. Tourist products that can compete with the existing product, be accepted by the consumers, and create demand are considered as new products. A new tourist product should be attractive and of interest to tourists. The World Tourism Organization (WTO) states that 300 different types of tourism can be invested in the tourism industry. New types of tourism and touristic products can be created for the tourism market. Service innovation in tourism refers to providing better service by creating guest satisfaction and differentiation of the service. Differentiation of the tourism product refers to the changes made in the existing product itself Touristic products can also be supportive of the main attraction. For example, local cuisine can be used as a supportive product within the scope of festival tourism. (Küçükaltan and Yıldız, 2009).

For the sustainability of tourism, new products developed apart from the existing ones will also increase the tourism supply. In particular, it is significant to implement new or improved ideas in the tourism industry. Examples of social innovation and social entrepreneurship in the tourism industry are given below.

"Green hotels" or "sustainable hotels" are considered innovative ideas in the tourism industry (Chang and Cheng, 2021). Environmentally friendly hotels are built using environmentally friendly materials and save energy and water, generate less waste, use recyclable materials, and train staff and guests towards environmental protection. Investors behave with an understanding of social and environmental responsibility. For example, international chains such as Hilton, Mariott, Hyatt, Accor, and many national branded hotels produce creative solutions to environmental pollution.

Similarly, eco-friendly accommodations are increasing. These "ecolodges" are located in unspoiled areas and built in harmony with nature using recyclable materials, which do not cause 
damage to the ecological system and biological diversity (Erdem and Tetik, 2013). Lapa Rios Ecolodge in Costa Rica was built from natural and recyclable materials. Solar energy is used for hot water in the hotel, and also plastic and glass materials are recycled.

Consisting of nine bungalows in harmony with nature in Brazil, Tauana Hotel is built from wood. Since the use of chemicals such as chlorine is avoided in the hotel, the hotel does not have a pool. Meals are prepared from organic food grown in the garden of the hotel. Operating in the UK, Strattons Hotel is one of the UK's leading award-winning eco-friendly hotels. All hotel staff have been trained in environmental protection. In Ayvalık, Cunda Ortunç Hotel, laundry is washed with environmentally friendly detergents, airport transfers are made by electric cars, and organic vegetables and fruits are used in food production (Gökdeniz and Dinç, 2017). In the Crowne Plaza Hotel in Copenhagen, guests help generate electrical energy by using a bicycle that is connected to a generator and thus enjoy their dinner free of charge (Vatan, 2010).

The tourism consortium, created under the name "Tasting Arizona" and consisting of food and beverage businesses, farmers, educational institutions, local people, festival organizations, aims to offer "local flavor" to customers in Arizona. For this purpose, a series of food products representing Arizona were determined (Carlsen and Edwards, 2008a). These innovative studies are particularly important as they support local businesses (farmers, food and beverage enterprises, etc.) and the local economy. Thus, the development of underdeveloped regions can be achieved with local development and equal distribution of incomes.

One of the best examples of social innovation is the idea of "farm to fork," which is becoming more popular all over the world. Based on this movement, the constant use of local, fresh, and natural products in food and beverage production, supplying products from local producers and farmers, thus ensuring that farmers survive in a competitive environment were aimed. These types of restaurants contribute to the elimination of food-related health problems by using food and beverages that are complied with food standards, using food and beverages that are not genetically modified, and are not polluted by chemicals in the production process. This system, which is also used as a regional development tool, helps small ethnic restaurants to survive by providing affordable and quality products and increases the competitiveness of local and small producers.

The Khama Rhino Sanctuary Trust has implemented a community-based tourism project in Botswana with the aim of conserving biodiversity (e.g., rhinos) and promoting the economic development of the local community with a socially innovative approach. Thus, the livelihoods of the local people improved, local employment increased, and the purchase of the goods and services produced by the local people caused the increase of small, medium, and micro-scale enterprises and the development of local arts and local economy (Stone and Stone, 2011).

The travel agency of Eco Travel Services, a social enterprise in Singapore, collaborating with non-profit organizations, and various social initiatives to conduct projects for the development of the rural villages within Vietnam, Laos, Thailand, Indonesia, Sri Lanka, and Bangladesh. Eco Travel provides homestay accommodation with the villagers, one-third of the income is given to families coming from visitors. In addition, it also trains villagers with the collaboration of Chiang Mai University and Singapore Management University where villagers are taught conversational English for effective communication with tourists. $25 \%$ of the revenue is donated to a community fund to finance public projects in the village (Biqi, 2012).

Nallihan's Rural Tourism Development Project is a social enterprise initiated in 2010 with the cooperation of the municipality, NGOs, and local people in order to benefit from the rural tourism potential of Nallihan. In the project, some of the idle public and private sector buildings were transformed into accommodation establishments and some into facilities where local products are sold and local food is offered (COMCEC, 2013). Thus, a significant increase was achieved in the income of the local people. 
DRAHNA, The Association of Environment, Development, Culture and Cooperation and the Association for Providing Services for Ulus and its Villages (APSUV), which aim to produce innovative solutions to the economic, social, and environmental problems faced by the rural communities living in Ulus district and villages (in Bartın province) and to create economic development have conducted various studies. "Development of Ecotourism-Based Guest House Project" was conducted in 2011 in order to increase the employment opportunities of the local people and to provide local accommodation for the visitors. For this purpose, 25 homeowners, mostly women, were trained on accommodation services, business administration, and environmental protection. The training program brought new skills to local women. Today, 10 guest houses meet the accommodation needs of the visitors. The project also created awareness about the protection and sustainability of the Küre Mountains National Park and forest ecosystem (Türker and Alaeddinoğlu, 2018).

The TaTuTa (Exchange of Agricultural Tourism on Organic Farms and Volunteer Experience) project, which was implemented in 2004 with the contribution of the Buğday Association for Supporting Ecological Living and the United Nations Development Program, aims to support the farmers engaged in ecological agriculture and to make people aware of the products they consume by considering the source and under what conditions they are produced. On the other hand, visitors participate in the production process and the workforce is exchanged mutually. Some of the visitors work voluntarily on these farms and receive accommodations free of charge. Some visitors pay for their accommodation and food and beverage services (Artuğer et al., 2013; Tatuta, 2018).

TaTuTa increases the information sharing of consumers and producers for ecological production and supports the production of sustainable resources that are compatible with nature for rural people. People who get bored with their routine urban life contribute to food production on these farms. In addition, this project contributes to the protection of biological diversity, soil, water, and air quality, climate, and ecosystem. These efforts are not only rural tourism or ecotourism activities but also an important and valuable example of social innovation-social entrepreneurship (Çiftçi, 2017).

Another social innovation example is the Slow Food movement that emerged in 1986 as a reaction to fast food restaurants in Italy. This trend is a social innovation that prioritizes respect for nature, adequate and healthy nutrition, embracing local tastes, and enjoying what we eat. The Citta slow concept emerged with the application of this trend to cities. Considering local resources, local culture, and history, slow food is integrated into slow cities. In slow cities, organic and healthy food are prioritized, local financial resources are used, and the local people emphasize the local culture. In these cities, natural and urban life is preserved, and an alternative way of life is offered in a stressfree and calm atmosphere, where also the quality of life of the local people increases. Sustainable living conditions offered in slow cities also contribute positively to tourism and improve the social and environmental quality. This movement, which prevails in Seferihisar district for the first time in Turkey, offers a holiday in a sustainable environment where nature and local culture are protected and where the negative impacts of mass tourism are eliminated (Kazançoğlu and Dirsehan, 2016).

As in many cases mentioned above, social innovation and social entrepreneurship in the tourism industry are aimed at protecting the ecological environment, increasing the education level and income of the local people, benefiting those who are socially disadvantaged, and encouraging sustainability, rather than making a profit. Social innovations in the tourism industry are mainly conducted in regions where people who need social support and have low income (Çiftçi, 2017).

In the relevant literature, there are only a few studies focusing on tourism, social innovation, and social entrepreneurship. Işık et al. (2018) state that international studies on innovation mainly focus on service and process innovation, but social innovation is also considered. Social innovation studies focus on eco-innovation, as enterprises attach importance to the solution of environmental problems as much as product, service, and process innovation. 


\section{METHODOLOGY}

The main purpose of this study is to develop innovative ideas and approaches for the tourism industry. For this purpose, a focus group study, which is a qualitative data collection method, was used in this study, and creative ideas about the tourism industry were collected from Tourism Master's students in Tourism Management and Entrepreneurship at a state university in Turkey. These groups were chosen as it is assumed that they have enough knowledge of the tourism industry and entrepreneurship.

A focus group is an unstructured discussion and meeting between a small group and a moderator with the aim of gaining in-depth information and generating ideas, using the effect of group dynamics (Bowling, 2002). Focus groups enable new and different ideas to emerge as a result of in-group interaction and group dynamics. Participants trigger feelings and thoughts in each other's minds because of mutual interactions and associations; thus, a rich flow of information is provided (Çokluk et al., 2011).

In this study, two groups were formed, consisting of 10 students studying in the Department of Tourism Management and 12 students studying in the Department of Entrepreneurship. Focus group interviews were completed in four different sessions, two with Tourism Management and two with Entrepreneurship students. The interviewees were informed about the subject of the interview and were included in the focus group meeting in line with their requests and approval. Krueger's (1994) "focus group information form" was used to collect data in these interviews, which lasted an average of 35-40 minutes. The interviews were recorded with the permission of the participants, the audio recordings were reported by transcribing verbatim in text, and the data were analyzed by content analysis.

\section{FINDINGS}

Two focus groups were formed in this study, which was conducted to reveal innovative social ideas and approaches in the tourism industry. The first group consisting of 10 people, 6 males and 4 females, studying in the Department of Tourism Management in a state university, while the second group, consisting of 6 females and 6 males, studied in the Entrepreneurship program.

\subsection{Focus Group Meetings Verbatim Document}

\subsubsection{Focus Group Meeting - 1}

The first focus group meeting attended by 10 participants who are the students of the Master's degree program at the Department of Tourism Management was held by an academic moderator on March 14, 2019. In the first focus group meeting, it was attempted to determine whether the students had knowledge about the concepts of innovation, social innovation, and social entrepreneurship. TM-P1 and TM-P3 explain these concepts as follows:

"Innovation is a novel idea. Social innovations are new ideas which people make when they realize their shortcomings in social areas. Since tourism is a social field, all kinds of social innovation can be easily applied." (TM-P1)

"Social innovation and social entrepreneurship are the realization of ideas to create a social change." (TMP3)

In the first Focus Group Meeting held with Tourism Management Master's Class students, basic information was given on social innovation and social entrepreneurship in the tourism industry, and detailed literature was discussed. Participants were asked to develop novel ideas and new approaches in the tourism industry. The second focus group discussion was planned a week later. Thus, the participants had time to develop novel ideas. 


\subsubsection{Focus Group Meeting - 2}

In the second focus group meeting held on March 21, 2019, innovative ideas of Department of Tourism Management students that will create economic, social, and environmental benefits to the community were collected. These ideas are presented in Table 1.

Table 1: Encoding Social Innovation and Social Entrepreneurship Ideas of Tourism Management Master's Class Students

\begin{tabular}{|c|c|c|c|}
\hline Participants & Ideas & Encoding of data & Themes \\
\hline TM-P1 & $\begin{array}{l}\text { Efforts on environmental protection, } \\
\text { recycling and decreasing waste in the } \\
\text { tourism industry, tax reduction for } \\
\text { tourism enterprises which provide } \\
\text { recycling. }\end{array}$ & $\begin{array}{l}\text {-Environmental } \\
\text { problems, } \\
\text {-Recycling, waste } \\
\text { management, } \\
\text {-Tax cutting to } \\
\text { promote recycling. }\end{array}$ & $\begin{array}{l}\text {-Protection of the natural } \\
\text { environment, } \\
\text {-State support for social } \\
\text { innovation through tax } \\
\text { reduction, } \\
\text {-Sustainable tourism } \\
\text { initiatives. }\end{array}$ \\
\hline TM-P3 & $\begin{array}{l}\text { Social innovation ideas that create } \\
\text { additional income for local people, } \\
\text { establishing local markets in big, } \\
\text { chained hotels, selling local and } \\
\text { organic products. }\end{array}$ & $\begin{array}{l}\text {-Local people to } \\
\text { benefit from tourism } \\
\text { revenues, } \\
\text {-Increasing the } \\
\text { consumption of local } \\
\text { products of tourists, } \\
\text {-Ensuring the } \\
\text { sustainability of } \\
\text { agricultural } \\
\text { activities, } \\
\text {-Strengthening the } \\
\text { agricultural } \\
\text { economy. }\end{array}$ & $\begin{array}{l}\text {-Contributing to the } \\
\text { development of rural areas, } \\
\text {-Fair distribution of } \\
\text { tourism income, } \\
\text { - Sustainable agriculture. }\end{array}$ \\
\hline $\begin{array}{l}\text { TM-P4, } \\
\text { TM-P5 }\end{array}$ & $\begin{array}{l}\text { Marketing of agricultural products to } \\
\text { hotels. For example, the sale of olives, } \\
\text { olive oil, grapes, and other products } \\
\text { grown in the Aegean Region to hotels } \\
\text { in the region, promoting local flavors, } \\
\text { reducing environmental pollution. }\end{array}$ & $\begin{array}{l}\text {-Providing social and } \\
\text { financial added } \\
\text { value in the supply } \\
\text { chain, } \\
\text {-Image studies, } \\
\text {-Reducing } \\
\text { environmental } \\
\text { pollution due to the } \\
\text { decrease in the } \\
\text { packaging of food. }\end{array}$ & $\begin{array}{l}\text {-Responsible/community- } \\
\text { based tourism, bi- } \\
\text { directional social } \\
\text { innovation that contributes } \\
\text { to reducing poverty and } \\
\text { protecting the } \\
\text { environment. }\end{array}$ \\
\hline $\begin{array}{l}\text { TM-P6, } \\
\text { TM-P3 }\end{array}$ & $\begin{array}{l}\text { "Barrier-Free Tourism", employing } \\
\text { staff at the hotels that can speak sign } \\
\text { language and can learn the Braille } \\
\text { Alphabet to serve tourists with } \\
\text { disabilities. }\end{array}$ & $\begin{array}{l}\text { - Barrier-Free } \\
\text { Tourism, } \\
\text {-Tourism for all. }\end{array}$ & $\begin{array}{l}\text { - Providing tourism } \\
\text { services to disadvantaged } \\
\text { groups, } \\
\text { - Raising awareness about } \\
\text { disabled people. }\end{array}$ \\
\hline TM-P7 & $\begin{array}{l}\text { The use of sign language software in } \\
\text { tourism businesses. }\end{array}$ & $\begin{array}{l}\text { - Communication } \\
\text { with disadvantaged } \\
\text { individuals. }\end{array}$ & $\begin{array}{l}\text {-Touristic product } \\
\text { development. }\end{array}$ \\
\hline TM-P8 & $\begin{array}{l}\text { Experiencing historical sites using } \\
\text { augmented reality devices. }\end{array}$ & $\begin{array}{l}\text { - Reducing the } \\
\text { impact of tourism on } \\
\text { historical sites, } \\
\text { - New tourist } \\
\text { experiences. }\end{array}$ & $\begin{array}{l}\text { - Drawing attention to } \\
\text { historical values and their } \\
\text { protection, } \\
\text { - Enriching the tourist } \\
\text { experience. }\end{array}$ \\
\hline TM-P9 & $\begin{array}{l}\text { Collection of rainwater and use in } \\
\text { hotels. }\end{array}$ & $\begin{array}{l}\text {-Water and energy } \\
\text { saving. }\end{array}$ & $\begin{array}{l}\text { - Environmentally sensitive } \\
\text { social innovation. }\end{array}$ \\
\hline TM- P10 & Kaplan Café & $\begin{array}{l}\text { - Raising awareness } \\
\text { for the protection of } \\
\text { endangered tigers } \\
\text { and other species. }\end{array}$ & $\begin{array}{l}\text {-Sustainability of } \\
\text { ecosystem. }\end{array}$ \\
\hline
\end{tabular}




\begin{tabular}{|c|l|l|l|}
\hline TM- P7 & Green Café & $\begin{array}{l}\text { - Tourism initiatives } \\
\text { where organic and } \\
\text { green products are } \\
\text { served (buttermilk, } \\
\text { compote, pickle juice, } \\
\text { etc.). }\end{array}$ & $\begin{array}{l}\text {-Sustainability of local } \\
\text { culture }\end{array}$ \\
\hline TM-P7 & Honesty Café & $\begin{array}{l}\text { - A business that is } \\
\text { completely based on } \\
\text { trust, where the } \\
\text { employees do not } \\
\text { work. }\end{array}$ & $\begin{array}{l}\text {-To instill honesty and trust } \\
\text { in children. }\end{array}$ \\
\hline
\end{tabular}

Participants express the issues related to innovative ideas as follows:

"Studies on this subject reveal that environmental problems are important in tourism. Generally, there are best practices at hotels and restaurants abroad, such as recycling, waste management, etc. However, there are only limited efforts on these issues in Turkey. For example, abroad, within the scope of the Green Line project, businesses that collect recyclable materials pay $10 \%$ less tax. Such projects may become widespread in Turkey. " (TM-P1)

"Local markets can be established in large hotels such as in chain hotels. In one section of the hotel, dry foods prepared by local women, handicrafts, and food such as pies or donuts can be prepared and sold. Thus, local people can earn additional income. Handicrafts (such as embroidery, lace) prepared by women, fruits, souvenirs that customers can both consume within the hotel and take with them to their homes can be sold. Similarly, local products can be supplied to hotels within the framework of an agreement signed by both parties. For example, fruits and vegetables grown in the Aegean region can be marketed to local hotels. Olives produced by local people are sold to hotels in Balkesir. Therefore, both tourists can be offered the opportunity to consume organic products, and local producers can easily find markets for their products. In other words, a win-win situation can be created." (TM-P3)

"Producing local flavors is an important issue. For example, hotels operating in the Aegean Region can create local flavors by using the products grown in the area. This also contributes to the hotel's image of locality and the reduction of pollution caused by transportation and packaging waste." (TM-P4)

"The tourism services provided for the disabled are quite limited. In this context, I have a socially innovative project such as the Barrier-Free Tourism. A hotel business can be initiated to serve the disabled and their companions, where employees work who have qualifications to communicate with the disabled. Today, many corporate companies employ staff who know sign language. This kind of staff can be employed in the tourism industry as well. All equipment in this hotel (bedroom, bathroom, pool, restaurant, etc.) should be constructed in a way that suitable for the disabled." (TM-P6)

"Do the disabled agree with this? Separation of other individuals and disabled people from each other can be viewed as discrimination." (TM-P4)

"By law, people with disabilities should be able to receive the same service under the same conditions as other people in all institutions and organizations. However, in many tourism enterprises, there are no sinks and pools they can use. The purpose here is not to separate other individuals from the disabled, but to create tourism facilities for them. Therefore, hotels for disabled will realize holidays they deserve by providing services that fit their needs." (TM-P3)

"I propose an innovation on augmented reality. For example, in the Netherlands, a phone software is used that displays the history of the museum visually when you hold your mobile phone facing the wall. It offers an incredible experience if this software is used with augmented reality glasses in historical places in Safranbolu or Istanbul. In addition, these areas cannot be destroyed as they are not physically visited, and their sustainability is ensured." (TM-P8) 
"As applied in South Korea, the rainwater can be collected by a system set up on the roadside, and this water can be used for road cleaning with an automatic system. Thus, rainwater is not wasted. Water saving and the efficient use of water are provided." (TM-P9)

"My idea is to initiate a café with the theme of tiger and forest. I imagine a café where the walls are covered with wallpaper or similar materials with a tiger pattern, and the carpets are decorated with tiger motifs. In this thematic café, which will mostly attract families with children, awareness of children towards poaching and endangered extinction of the tigers can be raised. It is known that there are 6 tigers among the 24 species of tigers existing in the world. Bengal tiger, Sumatra, white tiger, etc. Tigers' fur is used for luxury consumption." (TM-P10)

"Similar to the idea of Tiger café, a green or an eco-café can be initiated. Green and organic products can be served in this café. For example, buttermilk, compote, pickle juice, etc. For example, a Yörük-themed café can be established in the Mediterranean Region which reflects the nomadic culture." (TM-P7)

"An Honesty Café, as it is in Indonesia, can be established. In today's environment where people do not trust each other, honesty is a very important issue. In the cafe, no staff is employed, there is nobody at the checkout and no cashier. There are boxes with paper money and coins in the safe. You leave the money for the product you bought there. You also get the change (if there is any) yourself. In research, it has been determined that there is no deficit in the checkout of the cafe. There is a similar enterprise, a canteen at a school in Eskişehir in Turkey. It was observed that there was no money deficit in the safe, even an excess of money. With such practices, we can instill feelings of honesty and trust in children." (TM-P7)

\subsubsection{Focus Group Meeting - 3}

The first focus group meeting was held by the first author as a moderator at the Faculty of Business Administration on April 02, 2019, with the participation of 12 Master's students of the Department of Entrepreneurship. In the third focus group meeting, students were asked to define the concepts of innovation, social innovation, and social entrepreneurship concepts. Therefore, it has been attempted to determine whether students have enough knowledge about these concepts. ENP5 and EN-P6 explain the concepts as follows:

"Innovation is novelty while entrepreneurship refers to renew something that exists or to create a new enterprise which brings a social change. Similarly, social innovation is creating a new idea that did not exist before." (EN-P5)

"In my opinion, it is very important that the ideas are applicable and sustainable beyond being innovative. Moreover, these innovative social ideas should be appropriate to the culture and values of the society. The ideas that are not adopted by the society and are not sustainable will not applicable." (EN-P6)

In the 1st Focus Group meeting held with the students of the Entrepreneurship Master's program, students were informed exhaustively about innovation, social innovation, and social entrepreneurship, and students were asked to develop innovative ideas and new social approaches related to the tourism industry.

\subsubsection{Focus Group Meeting - 4}

In the second focus group meeting held on April 30, 2019, innovative ideas of Department of Entrepreneurship Master's students that will create economic, social, and environmental benefits in the tourism industry were collected. Data encoding and the content analysis results are presented in Table 2, 3, 4, and 5 respectively.

Table 2: Encoding Social Innovation and Social Entrepreneurship Ideas of Entrepreneurship Master's Class Students

\begin{tabular}{|c|l|l|l|}
\hline Participants & \multicolumn{1}{|c|}{ Ideas } & \multicolumn{1}{c|}{ Encoding of data } & \multicolumn{1}{c|}{ Themes } \\
\hline EN-P8 & Development of new types of tourism & - Developing new & - Rural development, \\
EN-P9 & in a region. & $\begin{array}{l}\text { touristic products in } \\
\text { accordance with the } \\
\text { EN-P10 }\end{array}$ & $\begin{array}{l}\text { - Efficient use of touristic } \\
\text { a region. }\end{array}$ \\
& & resources, \\
& & & \\
\hline
\end{tabular}




\begin{tabular}{|c|c|c|c|}
\hline & & & $\begin{array}{l}\text { - Diversification and } \\
\text { enriching of tourism } \\
\text { products. }\end{array}$ \\
\hline EN-P3 & $\begin{array}{l}\text { Establishing "hobby gardens" where } \\
\text { saffron cultivation is carried out }\end{array}$ & $\begin{array}{l}\text { - Saffron production } \\
\text { and hobby gardens } \\
\text { where tourists also } \\
\text { participate in the } \\
\text { production process. }\end{array}$ & $\begin{array}{l}\text { - Promotion of local } \\
\text { products, } \\
\text {-Sustainability of local } \\
\text { products and agricultural } \\
\text { activities, } \\
\text { - Enriching the tourist } \\
\text { experience. }\end{array}$ \\
\hline EN-P10 & $\begin{array}{l}\text { Developing heritage tourism in the } \\
\text { ancient city of Teion/Tios in the } \\
\text { Western Black Sea Region }\end{array}$ & $\begin{array}{l}\text { - Uncovering the } \\
\text { historical treasure of } \\
\text { our country, } \\
\text { - Development of } \\
\text { touristic activities. }\end{array}$ & $\begin{array}{l}\text { - Local development, } \\
\text { - Increase in employment, } \\
\text { - Increase in local people's } \\
\text { income. }\end{array}$ \\
\hline EN-P12 & $\begin{array}{l}\text { Developing tourism in Iznik and its } \\
\text { surroundings. Since the city is an } \\
\text { important religious center especially } \\
\text { for Christians, studies and initiatives } \\
\text { can focus on faith tourism. }\end{array}$ & $\begin{array}{l}\text { - Development of } \\
\text { tourism. }\end{array}$ & $\begin{array}{l}\text { - Initiatives for the } \\
\text { development of religious } \\
\text { tourism activities, } \\
\text { - Fair distribution of } \\
\text { tourism income, } \\
\text { - Contributing to the } \\
\text { development of rural } \\
\text { areas. }\end{array}$ \\
\hline EN-P5 & $\begin{array}{l}\text { Use of fishing boats for touristic } \\
\text { purposes in the Black Sea Region and } \\
\text { line fishing. }\end{array}$ & $\begin{array}{l}\text { - Boats where } \\
\text { tourists can acquire } \\
\text { fishing experience. }\end{array}$ & $\begin{array}{l}\text { - Additional income } \\
\text { generated by tourism, } \\
\text { - Promoting the local } \\
\text { culture, } \\
\text { - New and unique } \\
\text { touristic experiences. }\end{array}$ \\
\hline EN-P10 & $\begin{array}{l}\text { Environmental protection strategies } \\
\text { and environmental protection practices } \\
\text { of hotels. }\end{array}$ & $\begin{array}{l}\text { - Environmental } \\
\text { protection practices } \\
\text { are important } \\
\text { examples of social } \\
\text { innovation due to } \\
\text { their contribution to } \\
\text { the improvement of } \\
\text { environmental } \\
\text { quality. }\end{array}$ & $\begin{array}{l}\text {-Water and energy saving, } \\
\text { - Using renewable energy } \\
\text { sources, } \\
\text { - Parsing of waste, } \\
\text { - Organizing training } \\
\text { programs to increase } \\
\text { environmental awareness. }\end{array}$ \\
\hline EN-P6 & $\begin{array}{l}\text { The widespread use of bicycles in } \\
\text { touristic travels. Encouraging the use of } \\
\text { bicycles, especially among young } \\
\text { travelers. }\end{array}$ & $\begin{array}{l}\text { - Reducing the } \\
\text { carbon emissions } \\
\text { created by tourism. }\end{array}$ & $\begin{array}{l}\text { - Tourism that is sensitive } \\
\text { towards the environment } \\
\text { and health of tourists. }\end{array}$ \\
\hline
\end{tabular}

Participants' innovative ideas are given below:

"Although the sea, sand, and sun come to mind when tourism is mentioned, the tourism potential of Turkey shows that new tourism types can be developed. This provides rural development in underdeveloped areas." (EN-P8)

"Turkey has vast tourism resources. Especially in underdeveloped regions such as Eastern Anatolia, different types of tourism can be developed." (EN-P9)

"The annual amount of saffron production is very low in Safranbolu, which is the hometown of Saffron plant. Hobby gardens can be established to increase saffron production. A certain amount of saffron can be given to tourists working in hobby gardens. Therefore, on the one hand, it creates an important attraction for tourists. On the other hand, it creates an increase in saffron production. Saffron harvesting is carried 
out in a small area where Saffron agriculture has been made in recent years, and tourists also participate in this event." (EN-P3)

"Filyos hosts perhaps the second largest ancient city; Teion or Tios in the Black Sea Region. Excavations have been continuing in the ancient city for a long time. The areas that have been unearthed so far may create a touristic potential. There is no significant economic sector in the region to create employment. For this reason, the creation of a tourism movement in the ancient city and the development of tourism in the region may provide both the development of the region and the increase in employment. In this context, innovative ideas that will ensure the development of tourism in the region should be implemented. In this context, innovative entrepreneurs are needed." (EN-P10)

"I think that a similar tourism movement can gain momentum in Lake Iznik and its surroundings. Iznik is an important religious city for Christians where the first Ecumenical Council is gathered. The main source of income of the region is agriculture. Employment resources can be increased by developing different economic sectors such as tourism in the region." (EN-P12)

"Applications such as TATUTA farms can be carried out in many regions of Turkey." (EN-P1)

"The Black Sea is one of the most important fishing areas in our country. Combining fishing and tourism and using fishing boats for touristic purposes can provide additional income for fishermen. Fishing is a seasonal activity as it is limited to the fishing season. Therefore, fishing boats can be used for excursions outside the fishing season. As far as I know, there is no ban online fishing. So, tourists can fish in these boats. Fishermen can also earn additional income." (EN-P5)

"Today, environmental protection is vital. Hotels also cause many environmental problems with their disposal of waste, water, and energy use. In my opinion, the remarkable social innovation is the environmental protection efforts of hotels. For example, today many corporate hotels adopt environmental protection strategies such as water and energy saving, using renewable energy sources, sorting waste (such as batteries, paper, and plastic), recycling, organizing training programs to increase the environmental awareness of guests and employees." (EN-P10)

"Considering the carbon emissions in the world, it is seen that $5 \%$ of this emission is caused by the tourism industry. In recent years, the touristic travels of university students in the travel movement have been increasing, especially within the European Union. The widespread use of bicycles, especially among young people, may be a social innovation that increases environmental awareness." (EN-P6)

Table 3: Content Analysis of Students' Social Innovative Ideas Related to Protecting Natural Environment and Ensuring Local Development

\begin{tabular}{|c|l|l|}
\hline Participants & \multicolumn{1}{|c|}{ Innovative Tourism Ideas } & \multicolumn{1}{|c|}{ Content Analysis } \\
\hline TM-P1 & Tax cutting for enterprises having recycling programs. & $\begin{array}{l}\text { - Protecting the natural } \\
\text { environment. }\end{array}$ \\
\hline TM-P3 & $\begin{array}{l}\text { Establishing local markets and selling local products in } \\
\text { hotels. }\end{array}$ & $\begin{array}{l}\text { - Preservation of local } \\
\text { agricultural culture and } \\
\text { local development. }\end{array}$ \\
\hline $\begin{array}{l}\text { TM-P4, } \\
\text { TM-P5 }\end{array}$ & Sale of local agricultural products to hotels. & $\begin{array}{l}\text { - Organic food production } \\
\text { and local development. }\end{array}$ \\
\hline Tं-K9 & $\begin{array}{l}\text { The collection of rainwater and using it in tourism } \\
\text { enterprises. }\end{array}$ & $\begin{array}{l}\text { - Protecting the natural } \\
\text { environment. }\end{array}$ \\
\hline TM-P10 & Tiger Café. & $\begin{array}{l}\text { - Developing environmental } \\
\text { awareness and raising } \\
\text { awareness about } \\
\text { endangered animals. }\end{array}$ \\
\hline EN-P3 & Saffron cultivation in hobby gardens. & $\begin{array}{l}\text { - Sustaining local } \\
\text { agricultural culture and } \\
\text { local development. }\end{array}$ \\
\hline EN-P10 & Environmental protection practices of hotels. & $\begin{array}{l}\text { - Protecting the natural } \\
\text { environment. }\end{array}$ \\
\hline EN-P6 & Touristic trips by bicycle. & $\begin{array}{l}\text { - Protecting the natural } \\
\text { environment. }\end{array}$ \\
\hline
\end{tabular}


Table 4: Content Analysis of Students' Social Innovative Ideas Related to Product and Service Development and Improvement

\begin{tabular}{|c|c|c|}
\hline Participants & Innovative Tourism Ideas & Content Analysis \\
\hline $\begin{array}{l}\text { TM-P6, TM- } \\
\text { P3 }\end{array}$ & "Barrier-Free Tourism." & $\begin{array}{l}\text { - New product or service } \\
\text { development and/or } \\
\text { improvement. }\end{array}$ \\
\hline $\begin{array}{l}\text { EN-P8, } \\
\text { EN-P9, } \\
\text { EN-P10 }\end{array}$ & Development of new tourism types (Eastern Anatolia). & $\begin{array}{l}\text {-New product } \\
\text { development, rural } \\
\text { development, effective use } \\
\text { of touristic resources. }\end{array}$ \\
\hline EN-P10 & $\begin{array}{l}\text { Development of new touristic destinations (Teion/Tios, } \\
\text { Filyos Ancient City). }\end{array}$ & $\begin{array}{l}\text { - New product } \\
\text { development, local } \\
\text { development, preservation } \\
\text { of local culture. }\end{array}$ \\
\hline EN-P12 & $\begin{array}{l}\text { Development of new touristic destinations (religious } \\
\text { tourism in Iznik). }\end{array}$ & $\begin{array}{l}\text { - New product } \\
\text { development, rural } \\
\text { development, effective use } \\
\text { of touristic resources. }\end{array}$ \\
\hline EN-P5 & $\begin{array}{l}\text { Development of new tourism types (Fisheries in the Black } \\
\text { Sea). }\end{array}$ & $\begin{array}{l}\text { - New product } \\
\text { development, rural } \\
\text { development, effective use } \\
\text { of touristic resources. }\end{array}$ \\
\hline TM-P7 & Using sign language software in tourism establishments. & $\begin{array}{l}\text { - New service development } \\
\text { and/or improvement. }\end{array}$ \\
\hline TM-P7 & Green Café/Eco-café. & $\begin{array}{l}\text { - New product and service } \\
\text { development and/or } \\
\text { improvement, organic food } \\
\text { production. }\end{array}$ \\
\hline TM-P7 & Honesty Café. & $\begin{array}{l}\text { - New product or service } \\
\text { development and/or } \\
\text { improvement. }\end{array}$ \\
\hline
\end{tabular}

Table 5: Content Analysis of Students' Social Innovative Ideas Related to Information Technologies

\begin{tabular}{|c|l|l|}
\hline Participants & \multicolumn{1}{|c|}{ Innovative Tourism Ideas } & \multicolumn{1}{c|}{ Content Analysis } \\
\hline Tİ-K8 & $\begin{array}{l}\text { Experiencing historical areas using augmented } \\
\text { reality devices. }\end{array}$ & $\begin{array}{l}\text { - Using information technologies and } \\
\text { raising awareness about the } \\
\text { protection of historical sites. }\end{array}$ \\
\hline
\end{tabular}

\section{CONCLUSION}

This study was aimed at developing socially innovative ideas and approaches for the tourism industry. It was carried out with the Masters' students of the Department of Tourism Management and the Department of Entrepreneurship studying at a state university in Turkey, using the focus group method. In the study, students' socially innovative ideas that can be used in the tourism industry were collected. For this purpose, a total of four focus group meetings were held, two of which were consisting of Tourism Management and two Entrepreneurship Master's students. A total of 22 students, 10 of them Tourism Management and 12 Entrepreneurship, participated in the focus group interviews.

In the focus group discussions, students' innovative ideas focused on (1) developing new products/services, in other words, developing new tourism destinations and types of tourism, (2) 
rural development and environmental protection, and (3) using information technologies. The ideas are mainly: the development of alternative tourism types, creation of new destinations, ecologic food production and service, development of rural areas, increasing employment opportunities in rural areas, fair distribution of tourism income, sustainable tourism, protection of the natural and cultural environment, promotion, and sustainability of local culture, including support for local producers.

In the focus group discussions, it was determined that the students did not have detailed information on innovation, social innovation, social entrepreneurship, and social innovation in the tourism industry. However, the participants have relatively more knowledge about the concept of innovation compared to social innovation. For this reason, detailed information was given on these concepts before collecting the innovative ideas of students. This briefing was carried out separately in the first focus group meetings with both Tourism Management and Entrepreneurship Master's students. After the information was provided, it was determined that the social innovation and social entrepreneurship ideas of the students had matured.

As Tourism Management Master's students are engaged in tourism businesses, they produce more innovative ideas when compared to students of Entrepreneurship. In addition, it has been observed that Entrepreneurship Master's students have difficulties in generating ideas about social innovative practices in the tourism industry.

The development of tourism in the form of mass tourism brings along many negative economic, socio-cultural, and environmental problems at tourism destinations and on the local people living in the region (Chong, 2020). Solving these problems with a socially innovative approach is important for both the sustainable development of tourism (Moscardo, 2008) and the economic development of the local people, reducing poverty and increasing social welfare.

Currently, tourism is considered a driving force of development due to the labor opportunities it creates (Ladkin, 2011). For this reason, it serves as a catalyst for economic development and increases in employment opportunities, especially in underdeveloped rural areas (Jordan, HavadiNagy, and Maroşi, 2016). In this context, many social innovative projects, which were initiated by local governments and non-governmental organizations, have been implemented. However, the rapid development of technology, the changing and diversification of the needs and expectations of tourists, the increase in the environmental problems caused by tourism, and the existence of social and economic inequality among regions make it necessary to develop innovative approaches, applications, products, and services in tourism.

\subsection{Limitations}

The most important limitation of the study is that the data obtained from the focus group interviews were not tested by quantitative methods with a complementary study approach. In future studies, a questionnaire form should be created using the results of this research, and the findings obtained by qualitative methods should be confirmed with a quantitative method on a larger sample.

The results obtained from this study are limited to 22 participants studying at a state university, within Tourism Management and Entrepreneurship Master's programs. The small sample size limits the generalization of the results. Due to the nature of the study, the ideas/opinions that arise are subjective, and the findings cannot be generalized unless quantitative studies are conducted. However, this study is important as research on social innovation in the tourism industry is scarce.

\section{References}

Artuğer, S., Özkoç, A. G. and Kendir, H. (2013). Ta-Tu-Ta (tarım-turizm-takas) Çiftliklerinin Pazarlanması ve Tanıtılması İçin Öneriler. Uluslararası Sosyal ve Ekonomik Bilimler Dergisi, 3, 1-5. 
Asılsoy, B. (2016). Marka Konumlandırmasında Sosyal Girişimcilik Kavramının Önemi: Hizmet Sektöründe Bir Araştırma, İstanbul Ticaret Üniversitesi Sosyal Bilimler Enstitüsü İşletme Anabilim Dalı İşletme Yüksek Lisans Programı Yayımlanmış Yüksek Lisans Tezi, İstanbul

Ateş, M. (2018). Türkiye'de Sosyal İnovasyon Uygulamaları ve Genç Nüfusun Potansiyeli, SETA Siyaset, Ekonomi ve Toplum Araştırmaları Vakfı Yayını, https://setav.org/assets/uploads/2018/08/Analiz_ 253.pdf Accessed: 10 February 2019

Benevides, S. L. M., Pedro Filho, F., Madeira, M. J. A., Sakuno, I. Y. T., Arenhardt, V. (2018). Social Innovation by Tourism Strategy in the Western Amazon, International Journal of Advanced Engineering Research and Science, 5, 78-92.

BEPA (2011). Empowering people, driving change: Social innovation in the EU. Bureau of European Policy Advisers.

Betil, İ. (2010). Sivil Toplum, Sosyal Sermaye, Sosyal Girişimcilik, Girişimcilik ve Kalkınma Dergisi, 5(1), 2122.

Biqi, W. (2012). The Promise and Challenge of Ecotourism. Social Space, 106-109. https://ink. library.smu.edu.sg/cgi/viewcontent.cgi?article=1107\&context=lien_research Accessed in April 2021.

Bowling, A. (2002). Research Methods in Health: Investigating Health and Health Services. Philadelphia, PA: McGraw-Hill House.

Budak, G. (2015), Yoksulluğa İnovatif Bir Çözüm; Sosyal Girişimcilik, HAK-IŞ Uluslararası Emek ve Toplum Dergisi, 4 (8), 26-41

Carlsen, J. and Edwards, D. (2008) BEST EN case studies: Innovation for Sustainable Tourism, Tourism and Hospitality Research, 8, 1, 44-55.

Carlsen, J. and Edwards, D. (2008a). The Diablo Trust, Northern Arizona, USA, USA (in Eds. J. Carlsen, J. Liburd, D. Edwards, P. Forde) Innovation for Sustainable Tourism: International Case Studies http://www.greentrek.org/files/2013/08/Case_Study_Publication_full.pdf Accessed: 15 July 2018.

Chang, Y.Y. and Cheng, C.C. (2021). Evaluating the strategic implications of the service quality in green hotels from a new insight, Current Issues in Tourism, https:/ / doi.org/10.1080/13683500.2020.1868414

Chiklyaukova, E. (2015). Achieving growth through social innovation: A beyond GDP trial. Case studies of Turkey and Russia, Yüksek Lisans Tezi, Boğaziçi Üniversitesi/Sosyal Bilimler Enstitüsü/Uluslararası Ticaret Anabilim Dalı, İstanbul.

Chong, K.L. (2020). The side effects of mass tourism: the voices of Bali islanders, Asia Pacific Journal of Tourism Research, 25(2), 157-169. https:// doi.org/10.1080/10941665.2019.1683591

COMCEC (2013). Proceedings of the 1st Meeting of the COMCEC Tourism Working Group on "A New Trend in Sustainable Tourism Development: Community Based Tourism in the COMCEC Region, http://kalkinma.gov.tr/DocObjects/View/14988/PROCEEDINGS_OF_THE_1st_MEETING_OF_TH E_COMCEC_TOURISM_WORKING_GROUP.pdf.

Çiftçi, F. (2017). Turizm Sektöründeki Sosyal Girişim Çalışanlarının Sosyal Girişimcilik Davranışı, İş ve Yaşam Tatmini: Tatuta Projesi Narköy Örneği, Yüksek Lisans Tezi, Eskişehir Anadolu Üniversitesi Sosyal Bilimler Enstitüsü Turizm İşletmeciliği Anabilim Dalı.

Datta, P. B. (2011). Exploring the evolution of a social innovation: A case study from India. International Journal of Technology Management and Sustainable Development, 10(1),55-75.

Divisekera, S. and Nguyen, V.K. (2018). Determinants of innovation in tourism evidence from Australia, Tourism Management, 67, 157-167. https://doi.org/10.1016/j.tourman.2018.01.010

Dobele, L. (2015). Factors Which Influence the Development of Social Innovation in Latvia, Proceedings of the 2015 International Conference "ECONOMIC SCIENCE FOR RURAL DEVELOPMENT" No40 Jelgava, LLU ESAF, 23-24 April 2015, pp. 226-238.

Drius, M., Bongiorni, L., Depellegrin, D., Menegon, S., and Pugnetti, A. (2019). Tackling challenges for Mediterranean sustainable coastal tourism: An ecosystem service perspective, Science of The Total Environment, 652, 1302-1317. https://doi.org/10.1016/j.scitotenv.2018.10.121 
Ercan, S. (2016). Türkiye'de Sosyal Girişimcilik ve Yarattığı Etkilerin Değerlendirilmesi, İstanbul Teknik Üniversitesi, Yayımlanmış Yüksek Lisans Tezi, İstanbul.

Erdem, B. and Tetik, N. (2013). An Environmentally -Sensitive Approach in the Hotel Industry: Ecolodges, International Journal for Responsible Tourism, 2(2), 22-40.

Eren, H. (2010). Üniversite Öğrencilerinin Sosyal İnovasyon Kapasitelerinin Teknolojik Yenilikçilik Eğilimlerine Etkisini Ölçmeye Yönelik Bir Model Önerisi, Ankara: Kara Harp Okulu Savunma Bilimleri Enstitüsü

Ergul, M. and Johnson, C. (2011). Social Entrepreneurship in the Hospitality and Tourism Industry: An Exploratory Approach, Consortium Journal of Hospitality and Tourism, 16(2), 40-46.

European Commission. (2013). Guide To Social İnnovation-Regional And Urban Policy. Http://Ec.Europa.Eu/Regional_Policy/Sources/Docgener/Presenta/Social_İnnovation/Social_İnno vation_2013.Pdf

Goldenberg, M. (2004). Social Innovation In Canada, How Thenon-Profit Sector Serves Canadians and How It Can Serve Them Better. Canadian Policy Research Networks Inc. (CPRN), Research Report W25.

Gökdeniz, A. and Dinç, Y. (2017). Turizm Sektöründe Yeşil Pazarlama:Eko Oteller ve Ekolojik Uygulamalar, Karabük Üniversitesi Sosyal Bilimler Enstitüsü Dergisi, Özel Sayı 3, 29-39

Günlü, E. (2015). Sosyal Girişimcilik Olgusunun Kavramsal Analizi ve Turizmde Sosyal Girişimcilik, Sosyal ve Beşeri Araştırmalar Dergisi, 35

Halaç, D. S., Eren H., Bulut Ç. (2014). Sosyal Yenilikçilik: Bir Ölçek Geliştirme Çalışması. H.Ü. İktisadi ve İdari Bilimler Fakültesi Dergisi, 32(1), 165-190.

Haugh, H. (2005). A Research Agenda For Social Entrepreneurship. Social Enterprise Journal, 1(1), 1-13.

Işık, C., et.al. (2018) Turizm ve İnovasyon İlişkisi: Literatür Taraması, Journal of Tourism Intelligence and Smartness, 1(2),34-74.

Istanbullu Dincer, F., Akova, O., Mugan Ertugral, S., and Aydogan Ciftci, M. (2017). Green Innovation Practices in Hotel Enterprises, Eurasian Social Science Journal, 1, 58-73.

Jordan, P., Havadi-Nagy, K.X., and Maroşi, Z. (2016). Tourism as a driving force in rural development: Comparative case study of Romanian and Austrian villages, Tourism: An International Interdicsiplinary Journal, 64(2), 203-218

Kahvecioğlu, E.H. (2017). Sosyal İnovasyon ve Türkiye'deki Uygulamaları, Trakya Üniversitesi Sosyal Bilimler Enstitüsü İşletme Anabilim Dalı Yayımlanmamış Tezsiz Yüksek Lisans Projesi, Edirne

Kazançoğlu, İ. and Dirsehan, T. (2016). Sosyal İnovasyon ile Sakin Şehirler Arasındaki İlişkinin Sosyal Girişimciler Açısından incelenmesi: Seferihisar Örneği, Ege Stratejik Araştırmalar Dergisi, 7, 135-161

Krueger, R.A. (1994). Focus Groups- A Pratical Guidefor Applied Research, London, SAGE Pub.

Küçükaltan, G., Yıldız, Ö. E. (2009). “Turistik Ürün Çeşitlendirme Aracı Olarak Şarap Turizmi: Çeşme Örneği”. 10. Ulusal Turizm Kongresi, Turz. İsst. ve Otl. Y.O., Mersin Üni., Mersin, 1141-1155.

Ladkin, A. (2011). Exploring Tourism Labor, Annals of Tourism Research, 38(3), 1135-1155.

Li, K.X., Jin, M., and Shi, W. (2018). Tourism as an important impetus to promoting economic growth: A critical review, Tourism Management Perspectives, 26, 135-142. http://dx.doi.org/10.1016/j.tmp.2017.10.002

Martin, J.M.M., Martin, J.A.R., Mejia, K.A.Z., and Fernandez, F. A.S. (2018). Effects of Vacation Rental Websites on the Concentration of Tourists- Potential Environmental Impacts. An Application to the Baleric Islands in Spain, International Journal of Environmental Research and Public Health, 15(2), 347. https://doi.org/10.3390/ijerph15020347

Milliyet Newspaper (2013). Kaliteli bir yaşam için sosyal inovasyon 22.01.2013 tarihli makale http://www.milliyet.com.tr/yazarlar/dusunenlerin-dusuncesi/kaliteli-bir-yasam-icin-sosyalinovasyon-1659116/ Accessed: 10 February 2019.

Moscardo, G. (2008). Sustainable tourism innovation: Challenging basic assumptions, Tourism and Hospitality Research, 8(1), 4-13. 
Mulgan, G. (2006). The Process Of Social Innovation, Innovations. Technology, Governance, Globalization, 145-162, mitpress.mit.edu/innovations.

Neto, F. (2003). A new approach to sustainable tourism development: Moving beyond environmental protection, Natural Resources Forum, 27, 212-222.

Özdemir, F. and Ar, M. (2015), Sosyal Yenilik Üzerine Bir Alan Araştırması, ed.: Cevahir Uzkurt, İstanbul: Girişimcilik ve İnovasyon Yönetimi Dergisi, Sayı 1, Beta Basım Yayım Dağıtım A.Ş.

Özmete, E. and Gök, F. A. (2015). Sürdürülebilir Kalkınma İçin Sosyal İnovasyon ve Sosyal Hizmet İlişkisinin Değerlendirilmesi, Hacettepe Üniversitesi İktisadi ve İdari Bilimler Fakültesi Sosyal Hizmet Bölümü Dergisi, 26(2).

Öztaş, Kadir and Karabulut T., (2006), Turizm Ekonomisi Genel Turizm Bilgileri, 2. Basım, Nobel Yayınları, Ankara.

Perrini, F. and Vurro, C. 2006. Social Entrepreneurship: Innovation and Social Change across Theory and Practice. In Mair, J., Robinson, J. and Hockerts, K. (eds), Social Entrepreneurship, 5: 57-86. Basingstoke: Palgrave Macmillan.

Ruiz, C., and Parra, C. (2013). New forms of organization in knowledge-based societies: Social innovation. New York: Routledge.

Salman, A., Jaafar, M., and Mohamad, D. (2020). A comprehensive review of the role of Ecotourism in sustainable tourism development, e-Review of Tourism Research (eRTR), 18(2), 215-233.

Sartori, R., Costantini, A., Ceshi, A., and Tommasi, F. (2018). How Do You Manage Change in Organizations? Training, Development, Innovation, and Their Relationships, Frontiers in Psychology. 9:313. https://doi.org/10.3389/fpsyg.2018.00313

Sasidharan, V., Sirakaya, E., and Kerstetter, D. (2002). Developing countries and tourism ecolabels, Tourism Management, 23, 161-174.

Schumpeter, J. A. (1934). The theory of economic development: An inquiry into profits, capital, credit, interest, and the business cycle (C. 55). Transaction publishers.

Snyder, H., Witell, L., Gustafsson, A., Fombelle, P., and Kristensson, P. (2016). Identifying categories of service innovation: A review and synthesisof the literature, Journal of Business Research, 69(7), 2401-2408. http:/ /dx.doi.org/10.1016/j.jbusres.2016.01.009

Sofracı, İ. E. and Sarıkaya, B. (2017). Turizmde İnovasyon ve Girişimcilik Farklı Bir Turizm Anlayışı: TaTuTa Örneği. I. International Congress on Future of Tourısm: Innovation, Entrepreneurship and Sustainability Bildiriler Kitabı, Mersin/Türkiye, s. 452-456.

Stone, L.S. and Stone, T. M. (2011). Community-based tourism enterprises: challenges and prospects for community participation; Khama Rhino Sanctuary Trust, Botswana, Journal of Sustainable Tourism, 19 (1), 97-114

Tanimoto, K., Doi, M. (2007). Social Innovation Cluster In Action: A Case Study of the San Francisco Bay Area. Hitotsubashi Journal of Commerce and Management, 41, 117.

Taş, Y.H., Şemşek, İ. (2017). Türkiye ve Dünya'dan Sosyal Girişimcilik Örnekleri ve İstihdama Katkıları, HAKiş Uluslararası Emek ve Toplum Dergisi, 6(6).

Topsakal, Y. and Yüzbaşıŏlu, N. (2017). Sosyal İnovasyon Kavramsal Model Önerisi, Uluslararası Yönetim İktisat ve İşletme Dergisi, Cilt: 13, Sayı: 3.

Thakur, R. and Hale, D. (2013). Service innovation: A comparative study of U.S. and Indian service firms, Journal of Business Research, 66(8), 1108-1123. https://doi.org/10.1016/j.jbusres.2012.03.007

Türker, N. and Alaeddinoğlu, F. (2018). Ecotourism as a Social Innovation: Lessons From Turkey, 5th European Ecotourism Conference Proceedings Book, 10-12 Eylül 2018, Gürcistan.

Vasin, S.M., Gamidullaeva, L.A., and Rostovskaya, T.K. (2017). The Challenge of Social Innovation: Approaches and Key Mechanisms of Development, European Research Studies Journal, 20(2B), 25-45.

Vatan, A. (2010). Turizm işletmelerinde İnovasyon: İstanbuldaki 5 Yıldızlı Konaklama İşletmelerinde Bir Araştırma, Yüksek Lisans Tezi. 
Vatan, A. and Zengin, B. (2014). Çevresel İnovasyon ve Konaklama İşletmelerindeki Uygulamalar Üzerine Bir Araştırma: İstanbul Örneği. Akademik Sosyal Araştırmalar Dergisi,8, 511-530.

Zengin, B. ve Dursun, C. (2017). Otel İşletmelerinde Uygulanan İnovatif Faaliyetlerin Rekabet Avantaj1 Üzerine Etkileri: Doğu Marmara Örneği, Turizm ve Arastırma Dergisi, 6(2), 38-58.

http:/ / www.tatuta.org/?p=2\&lang=tr Accessed: 17 December 2018. 